\title{
OPERATION OF A PUBLIC GEOLOGIC CORE AND SAMPLE REPOSITORY IN HOUSTON, TEXAS
}

\section{$\underline{\text { Technical Progress Report }}$}

Reporting Period April 15, 2003 - April 15, 2004

by

Scott W. Tinker

Director and Principal Investigator

Laura C. Zahm

Research Associate and HRC Curator

and

Beverly Blakeney DeJarnett

Research Associate and HRC Curator

April 2004

for

U.S. Department of Energy

Award No. DE-FG26-02NT15290

Bureau of Economic Geology

John A. and Katherine G. Jackson School of Geosciences

The University of Texas at Austin

P.O. Box X, University Station

Austin, TX 78713-8924 


\section{DISCLAIMER}

This report was prepared as an account of work sponsored by an agency of the United States Government. Neither the United States Government nor any agency thereof, nor any of their employees, makes any warranty, express or implied, or assumes any legal liability or responsibility for the accuracy, completeness, or usefulness of any information, apparatus, product, or process disclosed, or represents that its use would not infringe privately owned rights.

Reference herein to any specific commercial product, process, or service by trade name, trademark, manufacturer, or otherwise does not necessarily constitute or imply its endorsement, recommendation, or favoring by the United States Government or any agency thereof. The views and opinions of authors expressed herein do not necessarily state or reflect those of the United States Government or any agency thereof. 


\title{
TABLE OF CONTENTS
}

\author{
Disclaimer 1

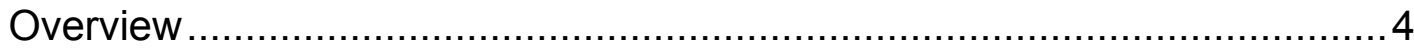

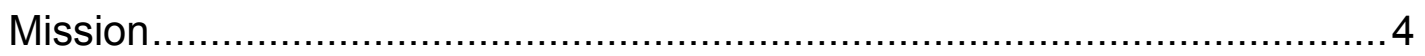

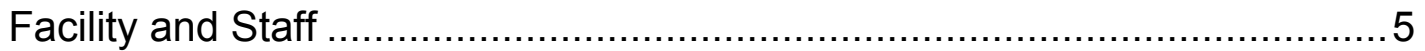

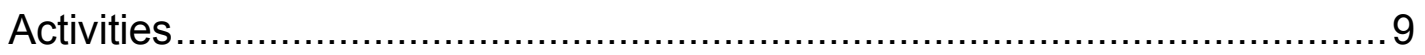

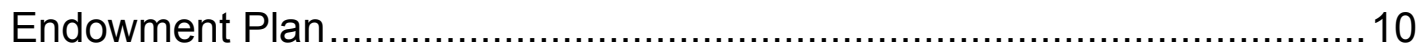

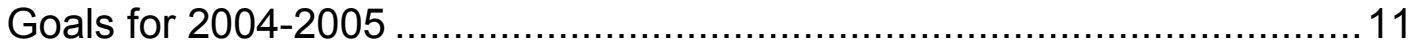




\section{Overview}

The Bureau of Economic Geology (BEG), building on an initial gift from BP, and with the continuing support of the Department of Energy (DOE), has established the first regional core and sample research center in Houston, Texas. The Houston Research Center (HRC) provides a state-of-the-art core layout facility, two fully equipped meeting rooms, and a comprehensive technical library, all available for public use. This document summarizes the activities, upkeep, increase in staff, and public impact on industry and the community that were accomplished at the Houston Research Center during its

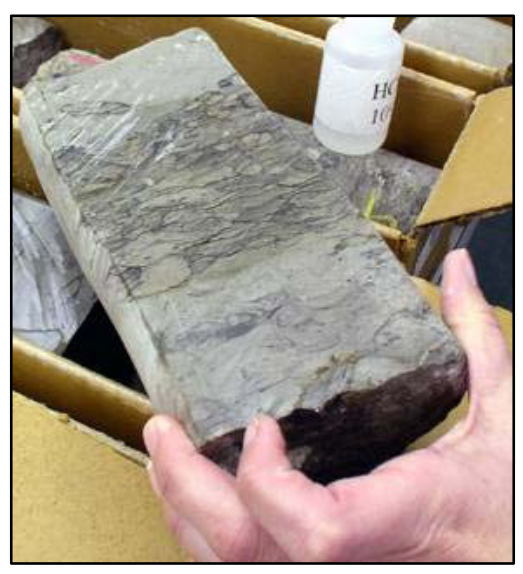
first two years of operation.

\section{Mission}

As part of the continuing dedication to serving the geologic community and setting high standards of excellence by The University of Texas at Austin, the HRC's mission is to: - provide access to geologic materials and a forum to conduct geologic studies with layout facilities, conference center, technical library, and a searchable, Web-based database.

- increase awareness of the value of rock materials through outreach programs.

- enable academic and industry members to promote and defend the importance of geologic material in the financial decision-making process.

- work with private industry and government to build both our collection and a cash endowment. The ultimate goal of our center is to build the endowment in order to cover our operating expenses and then eliminate all user fees, resulting in a true public geologic research center. 


\section{The Facility and Staff}

The Houston Research Center is not only a core and sample warehouse; it is a regional center for geologic research serving the geotechnical user community. Located in west Houston, six miles north of I-10 and two miles south of U.S. Highway 290, the HRC is easily accessible from any of Houston's major freeways. The facility is open 8 a.m. to 5 p.m., Monday through Friday. The HRC provides ample space for storing, viewing, and describing core and cuttings with rolling tables and microscopes, modern conference rooms for teaching and collaboration for groups of up to 200 people, a technical library, and a full staff for assistance.

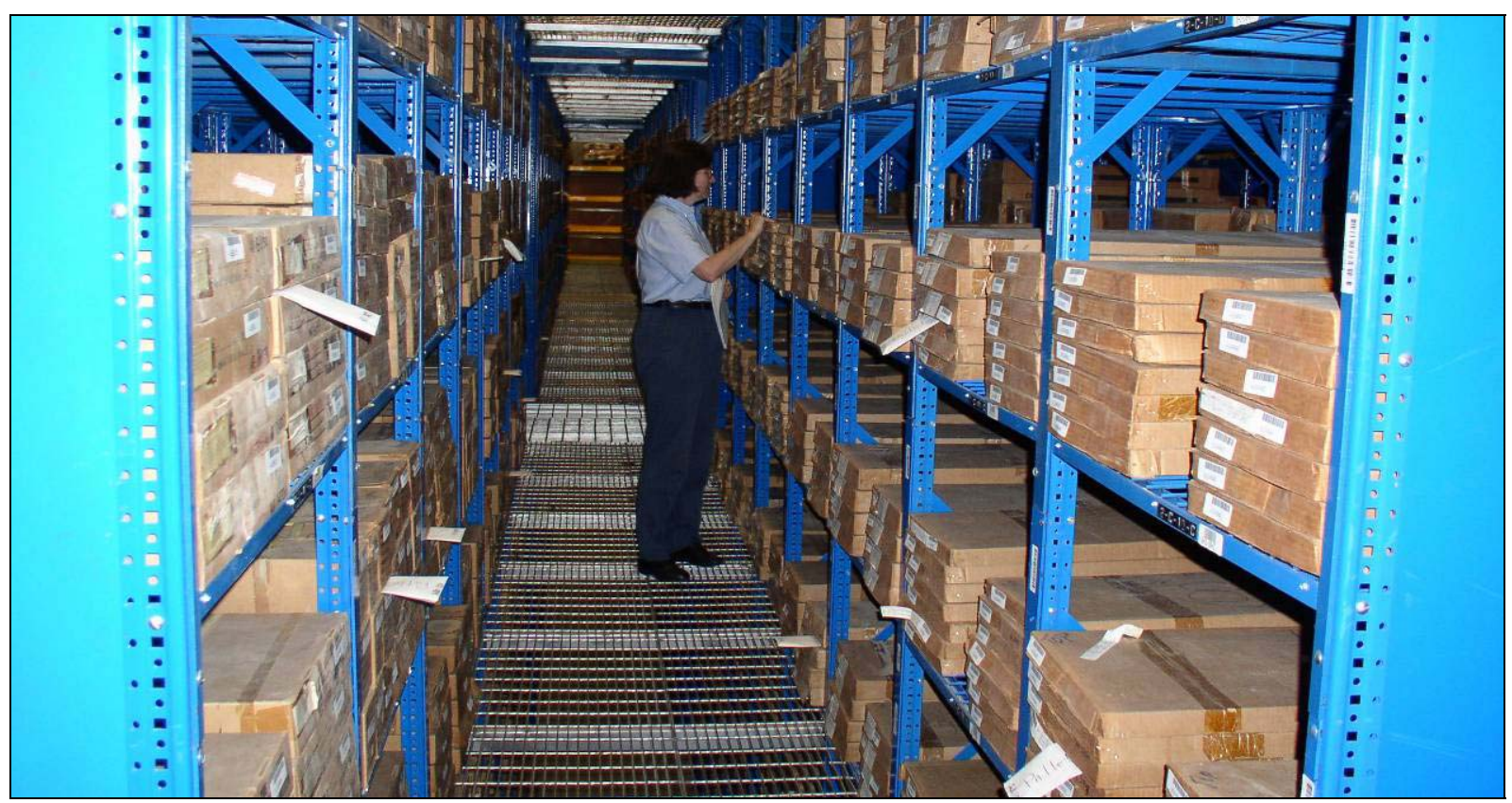

All interior space, including the core warehouse, is climate controlled. Elevated loading docks, specialized storage for frozen core, and basic rock preparation equipment make the HRC well designed for curation, easy access of materials, and research. Most of the cores, samples, and cuttings at the repository were acquired by private industry, but all are now available to the public. The collection in Houston adds to the existing BEG core and cuttings collections housed in Austin and Midland and brings the BEG holdings to more than 1.7 million boxes of geologic 
material available for public use. The collection includes onshore and offshore rock material from domestic as well as international locations.

The 2003-2004 year at the HRC saw several significant improvements. A complete technical library was donated by Unocal Corporation. The senior technical librarian from Unocal joined

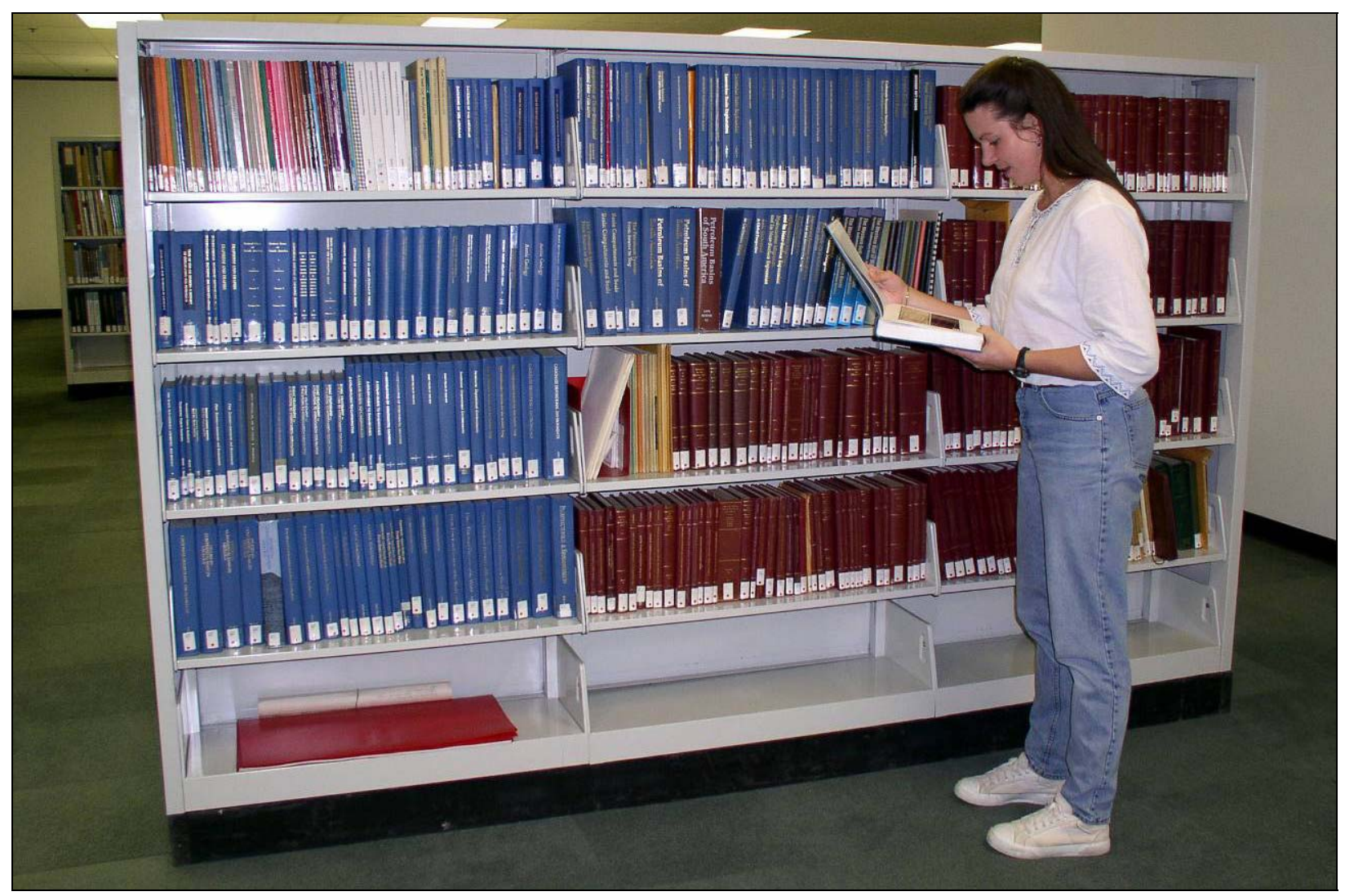

the HRC staff (Phyllis Vicars) in April 2004. The collection is a research-quality library and contains over 80,000 volumes with an emphasis on geology, geophysics, and petroleum engineering. It is housed in a newly renovated part of the facility in an over 4,000 square foot area. Valued at nearly $\$ 5$ million, the library includes books, more than 80 technical journals, maps, field guides, Federal Government reports, and monographs. The library is open to the public Tuesday-Friday from 10 a.m. to 4:00 p.m. 
As part of the library renovations, the HRC was able to increase capacity of the large conference room, now able to seat over 200 people with internet connections, a large podium, and complete audio visual equipment for meetings.

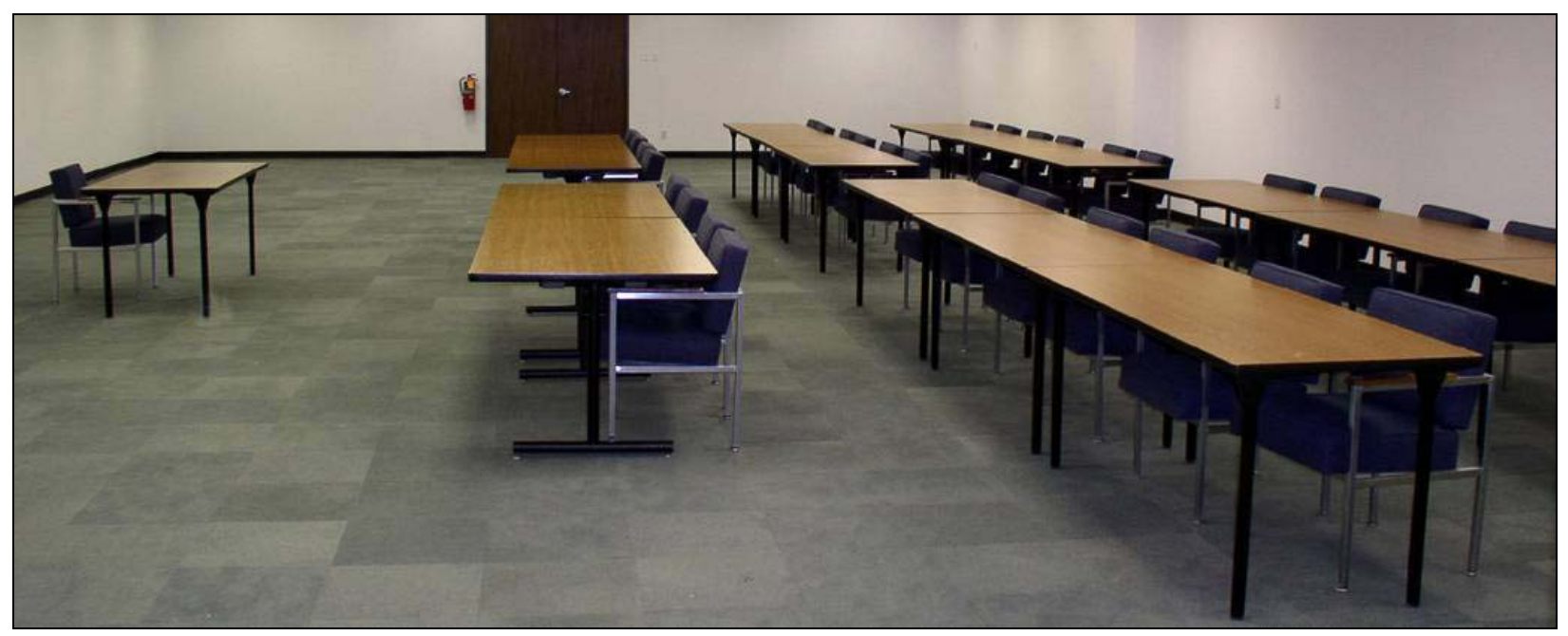

The HRC geologists (Beverly Blakeney DeJarnett and Laura Zahm), have worked diligently throughout the year to increase the use of the facility for meetings in the two conference rooms and geologic studies utilizing the core layout area. As a result, during 2003-2004, the HRC hosted workshops for the Houston Geological Society, the Petroleum Technology Transfer Council, and the National Science Foundation, In general, meetings and workshops at the HRC average 30 participants, and there are typically $1-2$ of these meetings per month. In addition to use of the conference rooms, use of the sample viewing and layout area has also dramatically increased to an average of 30 geoscientists per month. In early 2004, two petrographic microscopes and several binocular scopes were added for public use. One scope is equipped with digital photomicrograph capabilities. A

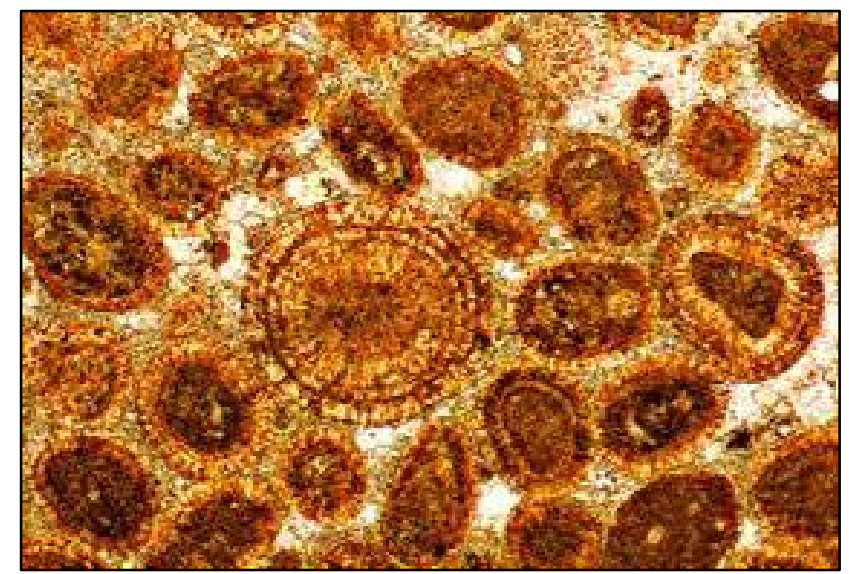


digital camera stand with proper lights was added to enable patrons to photograph key features as part of their geologic descriptions.

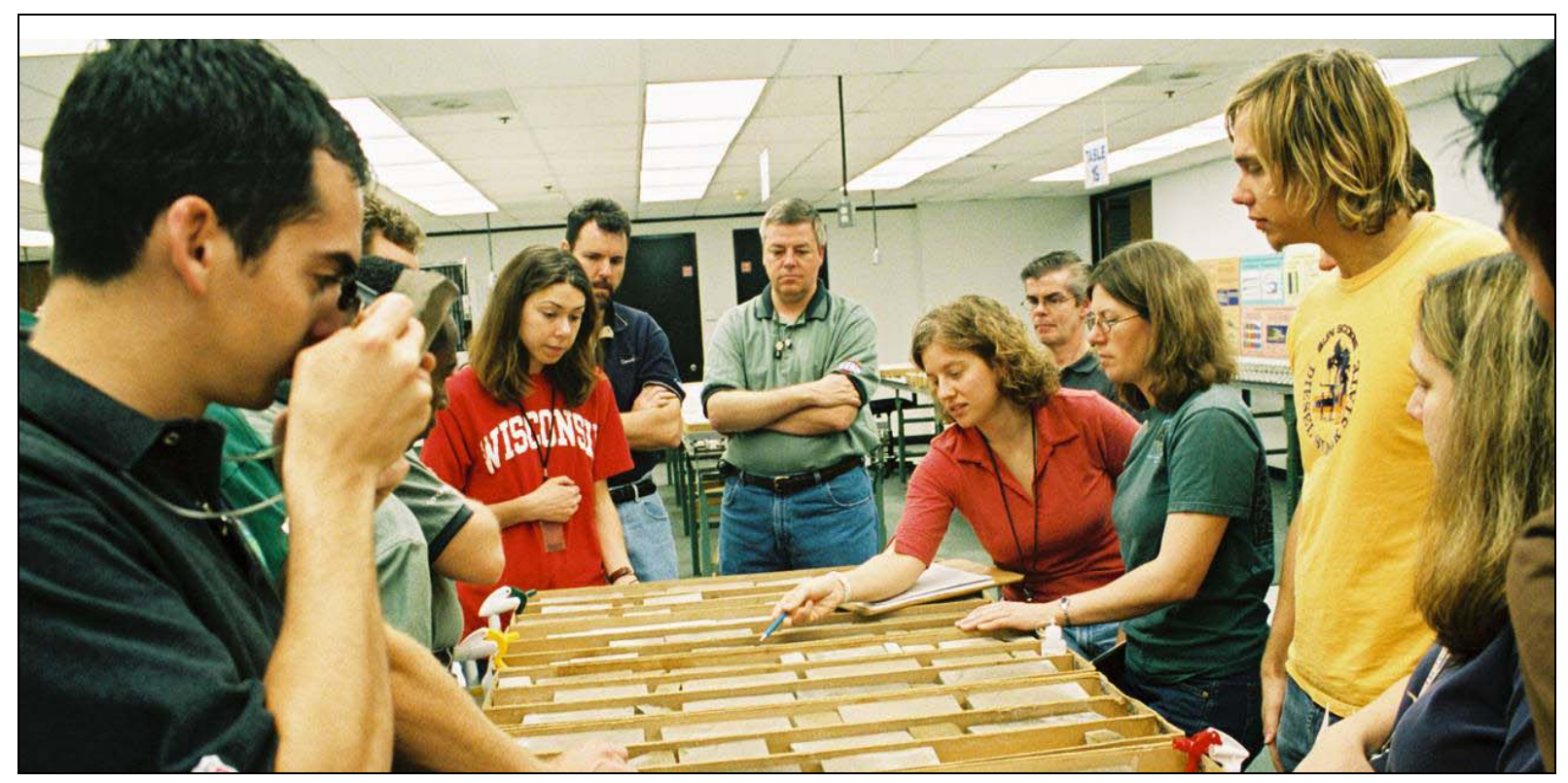

The warehouse staff at the HRC consists of Randy McDonald (Warehouse Supervisor) and

Darrell Haynes, who coordinate the core layout room usage and locate rock material for patrons.

During the 2002-2003 year the layout room was utilized on average by less than 5 people per month. This year use of the core layout facility increased to an average of 30 people per month laying out core material for workshops, short courses, and/or detailed geologic studies. In addition, scientists are accessing the HRC core collection by having material shipped directly to them on an average of four shipments per month.

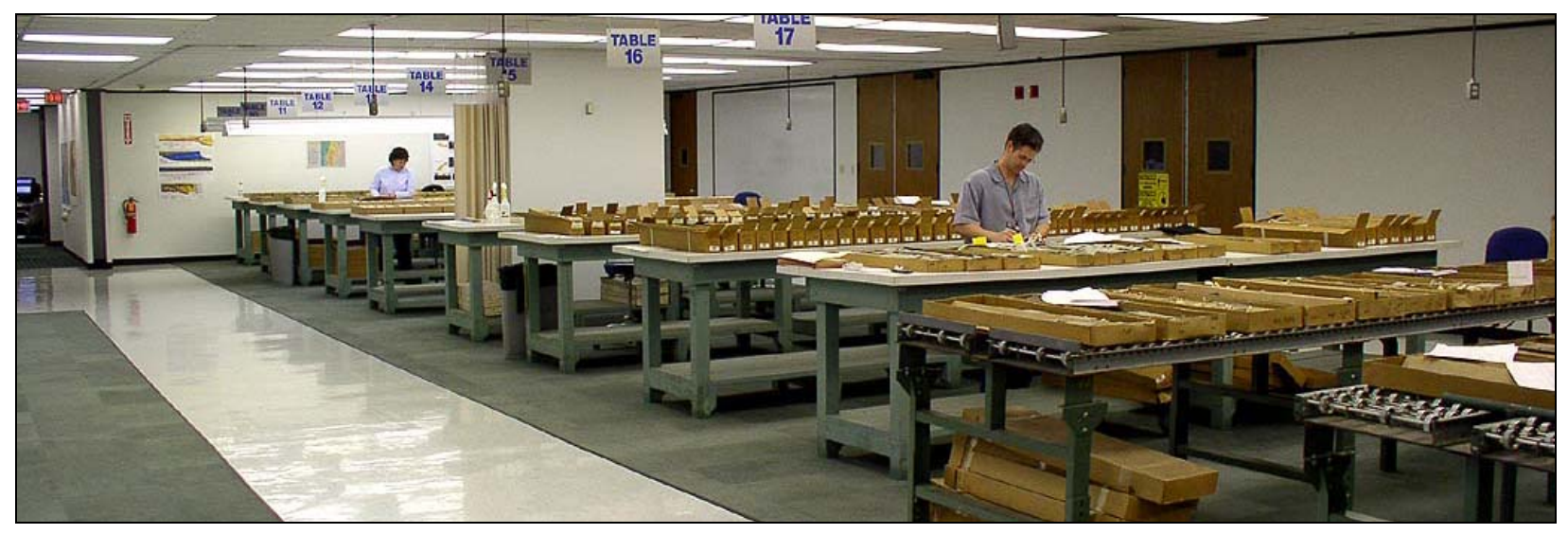


Interested geoscientists can access the online BEG database for a listing of all available geoscience data at the three BEG core research facilities (http://begdb1.beg.utexas.edu/ Igor/). This database is continually updated. Search criteria currently include state, county, depth, API, operator, lease, field, and well name. This database will soon be driven by a geographic information system (GIS) whereby rock material of interest can be located by selecting an area on a map.

A portion of the DOE funds are used for maintenance and upkeep of the HRC. In 2003-2004, some of the major repairs and expenses include maintenance of the air conditioning and heating system $(\$ 18,362.72)$, maintenance on equipment $(\$ 3,271.94)$, lighting and window repairs $(\$ 8,108.00)$, and pest control $(\$ 3,910.00)$.

\section{Activities}

The HRC has been featured in several recent technical publications, including Geotimes, AAPG Explorer, and the Houston Geological Society Bulletin and the Society for Independent Professional Earth Scientists (SIPES) Newsletter. HRC activities have dramatically increased as awareness of its existence as a regional geologic research center grows. Numerous geoscientists from both industry and academia have used the facility for workshops, core research, short courses, training of new employees, and meetings.

Public outreach activities for all age groups during 2003-2004 included a field trip for Earth Science Week for Houston Geological Society Members and their families, as well as several field trips for school, church, and scouting groups. 


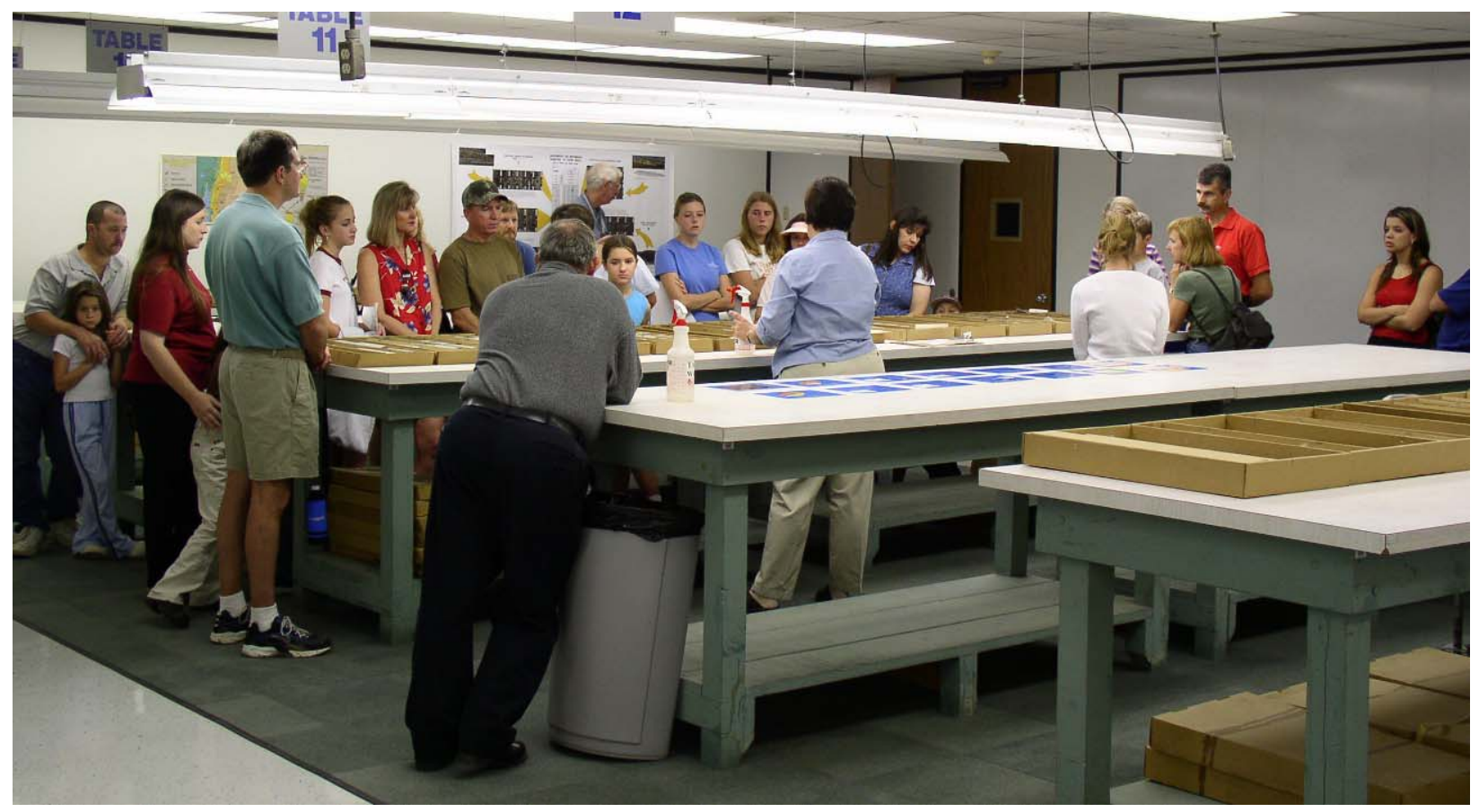

Organizations utilizing the HRC include: University of Houston, BP, Oxy, Petroleum

Technology Transfer Council, Department of Energy, Harvest Petroleum, ConocoPhillips, National Science Foundation, Science Teachers Association of Texas, Houston Geological Society, independent consultants, Santos, Sinopec, Halliburton, Justiss Oil, Shell, Gulf Coast CO2 Management, Nautilus, Anadarko, ExxonMobil, and Venoco.

In addition to outreach, a major focus of the HRC geologists' time is to work with industry partners to build up the HRC endowment and core collection. During 2004, the HRC has received donations from Oxy, XTO Energy, BP, Chesapeake, and independent consultants. Expected contributions prior to the end of the year are from Marathon, Amerada Hess, and ExxonMobil.

\section{Endowment Plan}

The BEG is striving to make the $\mathrm{HRC}$ a flagship public-sector core and sample repository in the United States. Originally built and operated by Amoco, the HRC was later acquired by BP, then 
donated to the BEG in late 2002. The original BP donation included physical facilities valued at $\$ 5.5$ million and \$1.5 million in cash. The donation consisted of the facility, including more than 12 acres of land, 108,000 square feet of warehouse and office space, machinery, equipment, geologic material, and furnishings. Occidental Petroleum, Inc. has also demonstrated their support with a cash donation and all domestic and international core material.

A generous multiyear granting program from DOE ( $\$ 300,000$ in 2002 and $\$ 350,000$ in 2003) has provided for many of the operational expenses of the HRC during its first years of operation. The BEG is actively pursuing donors of both rock material and cash to endow the facility. This endowment will reach a level in 5 years (see spreadsheet) where the interest earned on the endowment will cover operational expenses of the HRC well into the future. The BEG is currently in negotiation with four other petroleum companies that are interested in donating rock material and cash to the HRC.

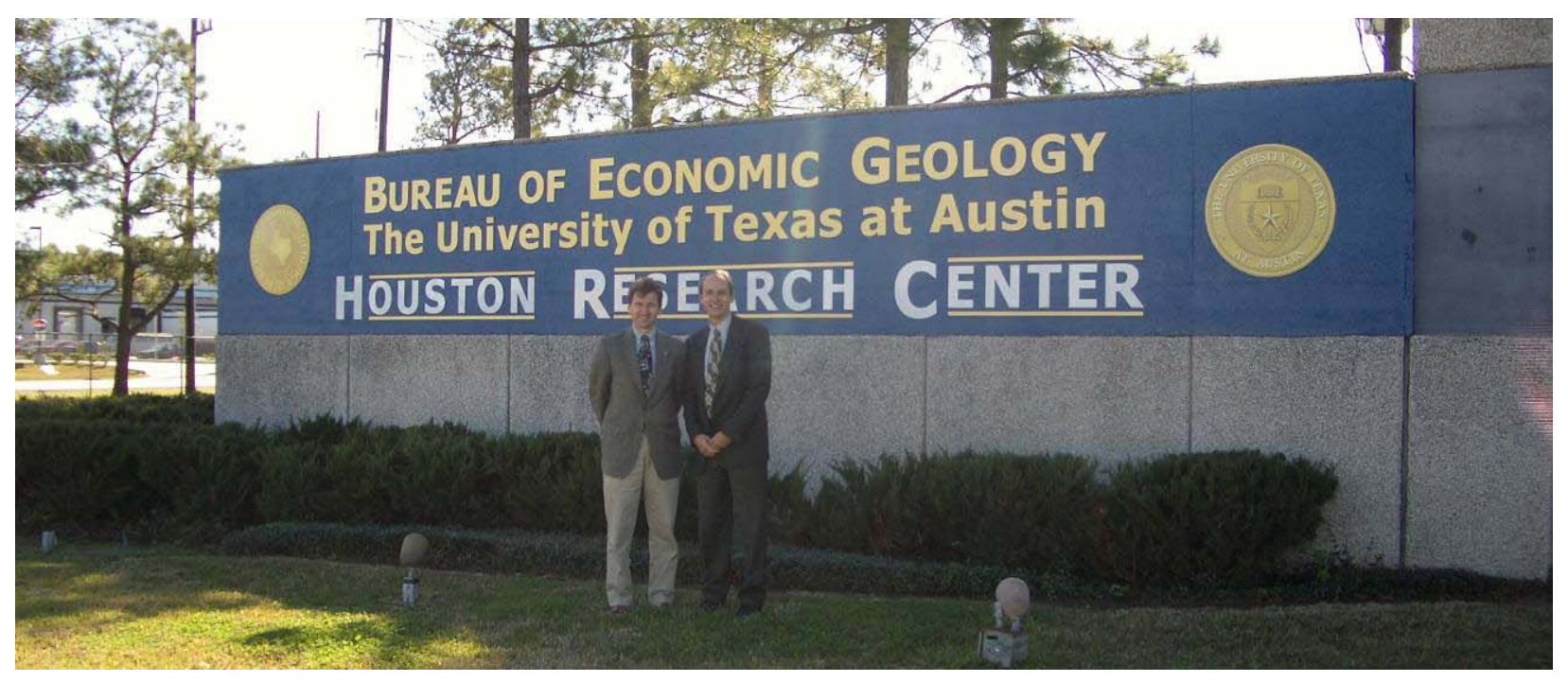

\section{Goals for 2004-2005}

The following goals are set for the upcoming year. The HRC will continue to improve the easy access of our geologic materials by the user community. The online database, a crucial interface 
between the core collection and the public, must continually improve to stay compatible with the ongoing Geoinformatics initiative. Some anticipated improvements include search ability by formation, ability to locate rock material from a GIS-driven map interface, and establishment of a teaching collection within the core collection searchable by depositional setting, geologic age, formation, or geologic basin. Public use of the core layout room and conference facilities must also continue to grow. This will be accomplished by continuing to increase public awareness of the HRC presence and capabilities.

Outreach activities will also increase. Each educational group that tours the $\mathrm{HRC}$ and learns about the interface between the geological sciences and the petroleum industry generates positive referrals to other school teaches or groups, resulting in more visitors. These outreach opportunities allow the HRC geologists to teach children about the earth sciences in an exciting way, therefore building positive experiences for these young minds as they learn about the geological

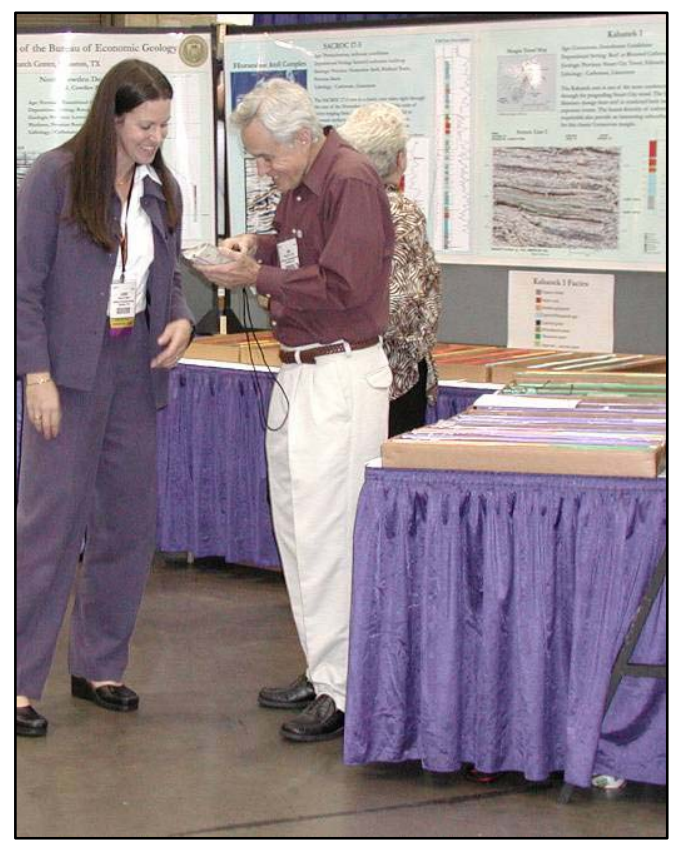
sciences.

In the coming year the HRC staff will continue to build our endowment through cash and core donations to achieve our established business plan. The HRC owes a great deal to the DOE for the continued support. 